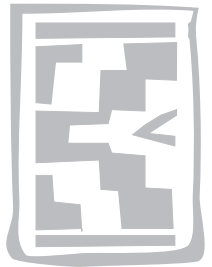

RESEARCH COMMUNICATION

\title{
Sequence and phylogenetic analysis of chicken anaemia virus obtained from backyard and commercial chickens in Nigeria
}

\author{
D.O. OLUWAYELU1 ${ }^{1}$, D. TODD ${ }^{2}$ and O.D. OLALEYE ${ }^{3}$
}

\begin{abstract}
OLUWAYELU, D.O., TODD, D. \& OLALEYE, O.D. 2008. Sequence and phylogenetic analysis of chicken anaemia virus obtained from backyard and commercial chickens in Nigeria. Onderstepoort Journal of Veterinary Research, 75:353-357

This work reports the first molecular analysis study of chicken anaemia virus (CAV) in backyard chickens in Africa using molecular cloning and sequence analysis to characterize CAV strains obtained from commercial chickens and Nigerian backyard chickens. Partial VP1 gene sequences were determined for three CAVs from commercial chickens and for six CAV variants present in samples from a backyard chicken. Multiple alignment analysis revealed that the $6 \%$ and $4 \%$ nucleotide diversity obtained respectively for the commercial and backyard chicken strains translated to only $2 \%$ amino acid diversity for each breed. Overall, the amino acid composition of Nigerian CAVs was found to be highly conserved. Since the partial VP1 gene sequence of two backyard chicken cloned CAV strains (NGR/Cl-8 and NGR/Cl-9) were almost identical and evolutionarily closely related to the commercial chicken strains NGR-1, and NGR-4 and NGR-5, respectively, we concluded that CAV infections had crossed the farm boundary.
\end{abstract}

Keywords: Chicken anaemia virus, cloning, sequence analysis

\section{INTRODUCTION}

Chicken anaemia virus (CAV) causes an economically important clinical and subclinical disease that is characterized by aplastic anaemia, thymus atrophy, intramuscular and subcutaneous haemorrhages, and immunosuppression in young chickens (McNulty 1991). The virus is found in the organs (Yuasa, Taniguchi, Imada \& Hihara 1983) and peripheral blood cells (Imai, Mase, Tsukamoto, Hihara \& Yuasa 1999) of infected chickens. Its genome consists of circular single-stranded DNA of $2.3 \mathrm{~kb}$

1 Department of Veterinary Microbiology and Parasitology, University of Ibadan, Ibadan, Nigeria

2 Veterinary Sciences Division, Department of Agriculture and Rural Development for Northern Ireland, Stormont, Belfast BT4 3SD, United Kingdom

3 Department of Virology, College of Medicine, University of Ibadan, Ibadan, Nigeria

Accepted for publication 14 August 2008-Editor that has three partially overlapping open reading frames coding for proteins of 52 (VP1), 24 (VP2) and 14 (VP3) kDa (Noteborn, De Boer, Van Roozelaar, Karreman, Kranenburg, Vos, Jeurissen, Hoeben, Zantema, Koch, Van Ormondt \& Van der Eb 1991). It is possible to differentiate naturally occurring CAV isolates using monoclonal antibody (Mab) reactivity (McNulty, Mackie, Pollock, McNair, Todd, Mawhinney, Connor \& McNeilly 1990) and DNA sequence determination (Renshaw, Soine, Weinkle, O'Connell, Ohashi, Watson, Lucio, Harrington \& Schat 1996). Since the genome sequence of CAV was first published (Noteborn et al. 1991), several low and highpassage CAV isolates have been sequenced (Meehan, Todd, Creelan, Earle, Hoey \& McNulty 1992; Renshaw et al. 1996; Islam, Johne, Raue, Todd \& Muller 2002).

Backyard chickens (Gallus gallus domesticus), which constitute about $80 \%$ of the estimated 150 million 
chicken population in Nigeria, have been implicated in the epidemiology of some viral diseases of poultry in the country (Abdu 1988; Ohore, Ozegbe, Emikpe \& Okojie 2002) and concerns have been expressed about their ability to harbour CAV. Recent serologic studies on commercial and backyard chickens in Nigeria revealed a high prevalence of CAV infection (Owoade, Oluwayelu, Fagbohun, Ammerlaan, Mulders \& Muller 2004; Emikpe, Oluwayelu, Ohore, Oladele \& Oladokun 2005; Oluwayelu 2006). While Ducatez, Owoade, Abiola \& Muller (2006) reported sequence diversity of Nigerian commercial chicken CAVs, they did not investigate backyard chicken flocks.

In the present study, we report the partial sequencing of the VP1 gene of three Nigerian commercial CAV strains, and the cloning and sequencing of CAV DNA obtained from Nigerian backyard chickens. The nucleotide and amino acid sequences of the commercial CAV strains were compared with those of the backyard chicken cloned CAV strains to determine the extent of genetic diversity between CAVs circulating in the two types of chickens.

\section{MATERIALS AND METHODS}

DNA was extracted from pooled liver and thymus tissues of commercial chickens as previously described (Oluwayelu, Todd, Ball, Scott, Oladele, Emikpe, Fagbohun, Owoade \& Olaleye 2005). Since tissue samples from infected backyard chickens were unavailable, sera of backyard chickens that were positive for CAV antibodies by a modified blocking enzymelinked immunosorbent assay (ELISA) were selected and DNA extracted from them. Polymerase chain reaction (PCR) was performed to amplify a fragment in the VP1 gene of CAV using primers and protocol as already described (Oluwayelu et al. 2005). Amplified CAV DNA fragments from one of the CAV antibody-positive backyard chicken sera were cloned into the plasmid vector, $\mathrm{pCR}^{\circledR} 2.1$ - $\mathrm{TOPO}^{\circledR}$ and transformed into TOP $10 \mathrm{E}$. coli using TOPO TA Cloning $^{\circledR}$ kit (Invitrogen). Plasmid DNAs of 12 selected colonies were purified using the Wizard ${ }^{\circledR}$ Plus Minipreps DNA purification kit (Promega) and subsequently digested with EcoRI enzyme. The PCR products of plasmids containing the inserts of interest were then sequenced. The three CAV strains from commercial chickens, designated NGR-1, NGR-4 and NGR-5 were sequenced bidirectionally using the BigDye ${ }^{\circledR}$ Terminator v3.1 cycle sequencing kit (Applied Biosystems). Amplification was done using the PCR primers as sequencing primers and the following thermal cycling conditions: $96^{\circ} \mathrm{C}$ for $1 \mathrm{~min}$, and then 25 cycles, each with $96^{\circ} \mathrm{C}$ for $10 \mathrm{~s}$, $50^{\circ} \mathrm{C}$ for $5 \mathrm{~s}$ and $60^{\circ} \mathrm{C}$ for $4 \mathrm{~min}$. Sequencing was carried out in an automated ABI 3100 DNA sequencer (Applied Biosystems). Purified DNAs of the six backyard chicken clones that were positive for the CAV insert following EcoRI digestion were similarly sequenced. They were designated $\mathrm{NGR} / \mathrm{Cl}-1$, $\mathrm{NGR} / \mathrm{Cl}-2, \mathrm{NGR} / \mathrm{Cl}-5, \mathrm{NGR} / \mathrm{Cl}-7, \mathrm{NGR} / \mathrm{Cl}-8$ and $\mathrm{NGR} / \mathrm{Cl}-9$. Sequence data obtained were analysed using the Vector NTI Advance 9 software (Invitrogen). Phylogenetic and molecular evolutionary analyses were conducted using MEGA version 4 (Tamura, Dudley, Nei \& Kumar 2007). The Genbank accession numbers of the Nigerian commercial chicken and backyard chicken cloned CAV strains, as well as those of the 11 reference CAV isolates are shown in Table 1.

\section{RESULTS AND DISCUSSION}

Amplification of DNA extracted from the commercial chicken tissues and backyard chicken sera yielded 733 bp CAV-specific bands. Alignment of the nucleotide sequence of the Nigerian CAV strains with those of reference isolates demonstrated $92-100 \%$ sequence identity, with $\mathrm{NGR} / \mathrm{Cl}-1$ and $\mathrm{NGR} / \mathrm{Cl}-7$ strains having $100 \%$ identity. With a maximum diversity of $6 \%$, the Nigerian commercial chicken CAV strains were more diverse than the backyard chicken cloned strains that had a maximum diversity of $4 \%$. While NGR-4 had the highest percentage identities with the backyard chicken cloned strains, there were high levels $(98 \%)$ of nucleotide identity between NGR-1 and a Malaysian strain (SMSC-1) and between NGR-4 and the Bangladeshi virus (BD-3). Alignment of the deduced amino acid sequences of all nine Nigerian strains showed an overall sequence identity of $97-100 \%$ while comparison of the sequences of the Nigerian and 11 reference CAV strains revealed that this fragment of the VP1 gene appeared to be highly conserved as only seven of the 20 strains compared had single amino acid substitutions not shared by others (Table2). Phylogenetic analysis of the nucleotide sequences of the $20 \mathrm{CAV}$ strains showed four major clusters (Fig. 1), with the backyard chicken cloned strains forming a unique cluster with Cux-1M, Cux-1N and cloned isolate 10. Also, phylogenetic analysis of the amino acid sequences of the $20 \mathrm{CAV}$ strains showed four major clusters (data not shown).

To date, there is no information about the characteristics of the CAV strains that infect avian species 


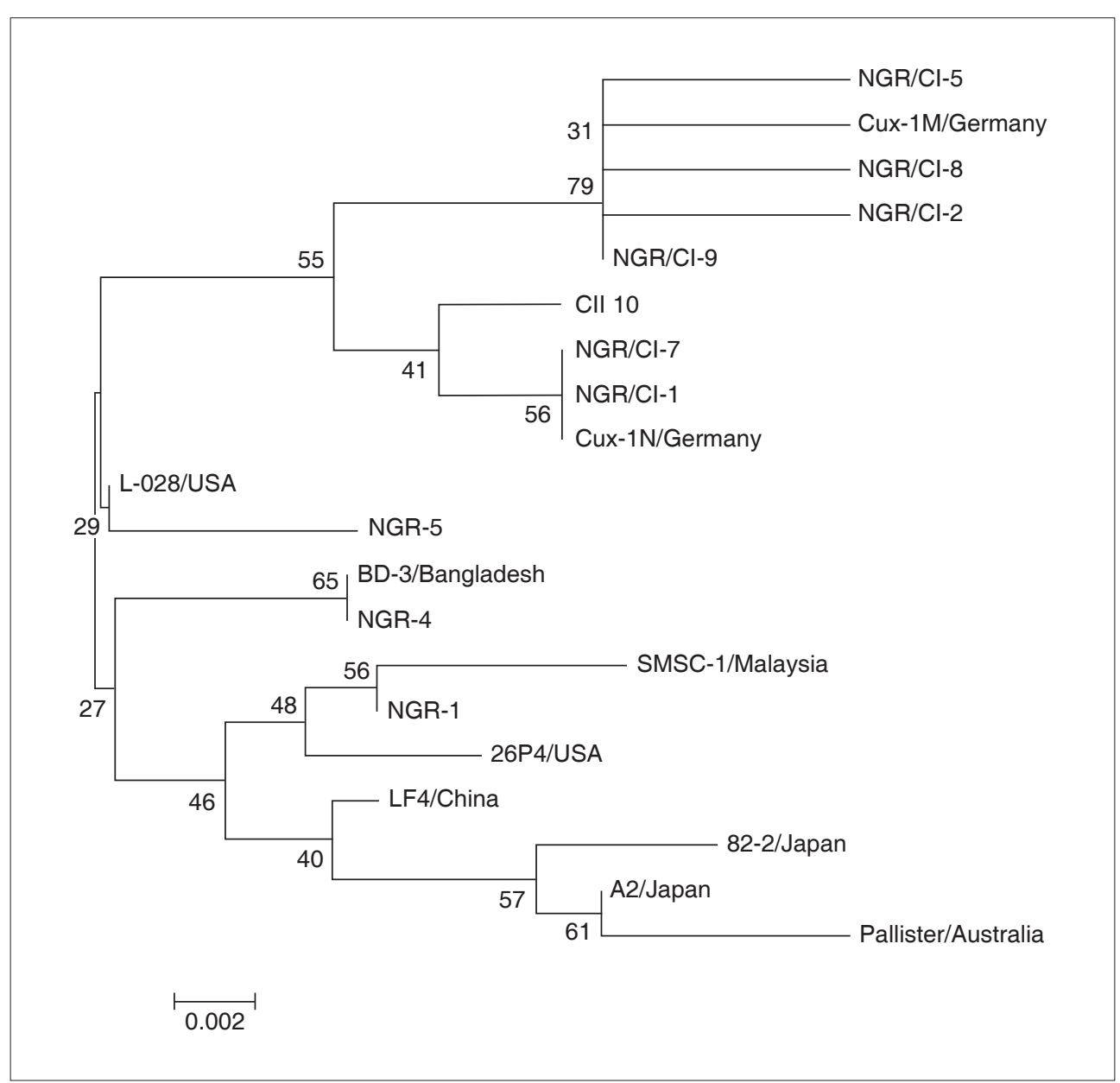

FIG. 1 Phylogenetic relationship among Nigerian and reference CAV strains based on nucleotide sequence of a fragment of the VP1 gene

TABLE 1 CAV sequences used for multiple alignment analysis

\begin{tabular}{|l|l|l|}
\hline Strain & Geographical origin & Genbank accession no. \\
\hline NGR-1 & Nigeria & AJ893509 \\
NGR-4 & Nigeria & AJ893510 \\
NGR-5 & Nigeria & AJ893511 \\
NGR/Cl-1 & Nigeria & AM279653 \\
NGR/Cl-2 & Nigeria & AM279654 \\
NGR/Cl-5 & Nigeria & AM279655 \\
NGR/Cl-7 & Nigeria & AM279656 \\
NGR/Cl-8 & Nigeria & AM279657 \\
NGR/Cl-9 & Nigeria & AM279658 \\
Cux-1M & Germany & M81223 \\
Cux-1N & Germany & M55918 \\
BD-3 & Bangladesh & AF395114 \\
SMSC-1 & Malaysia & AF285882 \\
A2 & Japan & AB031296 \\
$82-2$ & Japan & D31965 \\
LF4 & China & AY839944 \\
L-028 & USA & U69549 \\
$26 P 4$ & USA & D10068 \\
Pallister & Australia & S71488 \\
Cloned isolate 10 (Cll 10) & UK & U66304 \\
\hline
\end{tabular}


Chicken anaemia virus obtained from chickens in Nigeria

TABLE 2 Amino acid differences between Nigerian and reference CAV strains (Numbering according to Meehan et al. 1992.)

\begin{tabular}{|c|c|c|c|c|c|c|c|c|c|c|c|c|c|}
\hline \multicolumn{14}{|c|}{ Amino acid position } \\
\hline Strain & 251 & 254 & 265 & 275 & 287 & 290 & 294 & 299 & 321 & 322 & 357 & 364 & 370 \\
\hline Consensus & $\mathbf{Q}$ & E & $\mathbf{N}$ & $\mathbf{Y}$ & A & A & $\mathbf{Q}$ & $\mathbf{N}$ & A & $\mathbf{R}$ & v & I & $\mathbf{S}$ \\
\hline NGR-1 & $\mathrm{R}$ & $\cdot$ & $\mathrm{T}$ & $\cdot$ & $\mathrm{T}$ & $\cdot$ & $\cdot$ & $\cdot$ & $\cdot$ & Q & $\cdot$ & $\cdot$ & $\cdot$ \\
\hline NGR-4 & $\mathrm{R}$ & $\cdot$ & $\mathrm{T}$ & . & · & $\cdot$ & . & . & $\cdot$ & $Q$ & . & $\cdot$ & $\mathrm{T}$ \\
\hline NGR-5 & $\mathrm{R}$ & $\cdot$ & $\mathrm{T}$ & $\mathrm{C}$ & $\cdot$ & $\cdot$ & $\cdot$ & $\cdot$ & $\cdot$ & Q & $\cdot$ & $\cdot$ & $\cdot$ \\
\hline $\mathrm{NGR} / \mathrm{Cl}-1$ & $\cdot$ & $\mathrm{G}$ & $\mathrm{T}$ & $\cdot$ & $\cdot$ & $\cdot$ & $\cdot$ & $\cdot$ & $\cdot$ & $Q$ & . & $\cdot$ & $\cdot$ \\
\hline NGR/Cl-2 & $\cdot$ & $\cdot$ & $\cdot$ & . & $\cdot$ & $\cdot$ & . & . & $\cdot$ & Q & $\cdot$ & $\mathrm{T}$ & $\cdot$ \\
\hline NGR/Cl-5 & . & . & $\cdot$ & . & . & . & . & . & . & $Q$ & $M$ & . & $\cdot$ \\
\hline $\mathrm{NGR} / \mathrm{Cl}-7$ & - & $\mathrm{G}$ & $\mathrm{T}$ & $\cdot$ & $\cdot$ & $\cdot$ & $\cdot$ & $\cdot$ & $\cdot$ & Q & $\cdot$ & $\cdot$ & $\cdot$ \\
\hline NGR/Cl-8 & . & . & $\cdot$ & . & . & . & . & . & $\cdot$ & . & . & . & $\cdot$ \\
\hline NGR/Cl-9 & . & . & $\cdot$ & . & . & $\cdot$ & . & . & $\cdot$ & Q & . & $\cdot$ & $\cdot$ \\
\hline Cux-1M & $\cdot$ & . & $\cdot$ & . & . & $\cdot$ & . & . & $\mathrm{R}$ & $Q$ & . & . & . \\
\hline Cux-1N & $\cdot$ & $\mathrm{G}$ & $\mathrm{T}$ & $\cdot$ & $\cdot$ & $\cdot$ & $\cdot$ & $\cdot$ & $\cdot$ & $Q$ & $\cdot$ & $\cdot$ & $\cdot$ \\
\hline BD-3 & $\mathrm{R}$ & $\cdot$ & $T$ & . & . & $\cdot$ & . & . & $\cdot$ & $Q$ & . & $\cdot$ & $\mathrm{T}$ \\
\hline SMSC-1 & $\mathrm{R}$ & $\cdot$ & $\mathrm{T}$ & . & $\mathrm{T}$ & $P$ & $P$ & . & $\cdot$ & $Q$ & $\cdot$ & $\cdot$ & $\cdot$ \\
\hline A2 & $\mathrm{R}$ & . & $\mathrm{T}$ & . & $S$ & . & . & . & . & $Q$ & . & . & G \\
\hline $82-2$ & $\mathrm{R}$ & $\mathrm{G}$ & $T$ & . & $S$ & $\cdot$ & . & . & $\cdot$ & $Q$ & . & $\cdot$ & $\mathrm{G}$ \\
\hline LF4 & $\mathrm{R}$ & . & $T$ & . & $S$ & . & . & . & $\cdot$ & $Q$ & . & $\cdot$ & $\cdot$ \\
\hline L-028 & $\mathrm{R}$ & . & $\mathrm{T}$ & . & . & . & . & . & . & $Q$ & . & . & $\cdot$ \\
\hline $26 \mathrm{P} 4$ & $\mathrm{R}$ & $\mathrm{G}$ & $\mathrm{T}$ & $\cdot$ & $\mathrm{T}$ & $\cdot$ & $\cdot$ & $\cdot$ & $\cdot$ & Q & $\cdot$ & $\cdot$ & $\cdot$ \\
\hline Pallister & $\mathrm{R}$ & . & $\mathrm{T}$ & . & $S$ & . & . & Y & $\cdot$ & $Q$ & $\cdot$ & $\cdot$ & G \\
\hline CII 10 & . & $Q$ & $\mathrm{~T}$ & . & . & . & . & . & . & $Q$ & . & . & . \\
\hline
\end{tabular}

Amino acid residues similar to that of the consensus are indicated as dots (•)

other than commercial chickens. Serologic surveys have shown that CAV infection is prevalent in backyard chickens in Nigeria (Emikpe et al. 2005; Oluwayelu 2006). The CAV strains that infect backyard chickens may thus provide a basis for better understanding of the epidemiology of chicken infectious anaemia (CIA). This study, which is the first report on CAVs from backyard chickens in Africa, is based on the genetic diversity of a fragment of the VP1 gene of three commercial and six backyard chicken cloned CAV strains. The detection of 733 bp CAV DNAs by the PCR in these chickens confirmed the presence of CAV in the chickens.

The $6 \%$ and $4 \%$ nucleotide diversity obtained for the Nigerian commercial and backyard chicken strains respectively translated to only $2 \%$ diversity for both types of chickens at the amino acid level. Since NGR/Cl-1 and NGR/Cl-7, which were $100 \%$ identical at the nucleotide level were also $100 \%$ identical at the amino acid level, it is likely that they are the same CAV strain. NGR-4 and NGR-5 that did not grow in MDCC-MSB1 cells (Oluwayelu et al. 2005), formed a cluster with BD-3, which also did not grow in MDCC-MSB1 cells in a previous study (Islam et al. 2002) but the molecular basis for this has not yet been investigated. Renshaw et al. (1996) suggested that ${ }^{139} Q$ and/or ${ }^{144} Q$ affected the rate of replication or spread of infection in MDCC-MSB1 cells. It is likely that NGR-4 and BD-3 on one hand, and NGR-1 and SMSC-1 on the other, share common evolutionary origins. Since vaccination against CAV is not done in Nigeria at present, it is possible 
that these CAV strains were introduced into the country through importation of infected poultry, poultry vaccines or other biologicals.

The close association of the Nigerian backyard chicken CAV strains with the commercial chicken strains in terms of genetic relatedness is an indication that CAV infection is not restricted to the farm premises. The virus may have spread from the farm to the backyard chickens, or vice versa. The practice of culling and selling spent layers, some of which may be harbouring the virus and ultimately end up as backyard chickens, may contribute to dissemination of this virus in the field. The detection of six distinct CAV variants from backyard chickens in this study, coupled with the fact that Nigerian backyard chickens contain a mixed population of different breeds, suggest a need for further investigation of CAV sequence diversity in these chickens and an evaluation of the specific economic losses caused by backyard chicken CAV strains to the Nigerian poultry industry.

\section{ACKNOWLEDGEMENTS}

The authors gratefully acknowledge the John D. and Catherine T. MacArthur Foundation for supporting this work with a staff development grant awarded to D.O. Oluwayelu. We also thank Mr C.A. Latunji and Dr A. Ayinmode of the Departments of Zoology and Veterinary Microbiology and Parasitology, University of Ibadan, respectively, for their assistance in the phylogenetic analysis. We thank Drs O.A. Oladele and B.O. Emikpe of the Faculty of Veterinary Medicine, University of Ibadan, who assisted with the collection of samples.

\section{REFERENCES}

ABDU, P.A. 1988. Infectious bursal disease in a flock of broilers and local Nigerian chickens. Bulletin of Animal Health and Production in Africa, 36:269-271.

DUCATEZ, M.F., OWOADE, A.A., ABIOLA, J.O. \& MULLER, C.P. 2006. Molecular epidemiology of chicken anemia virus in Nigeria. Archives of Virology, 151:97-111.

EMIKPE, B.O., OLUWAYELU, D.O., OHORE, O.G., OLADELE, O.A. \& OLADOKUN, A.T. 2005. Serological evidence of chicken anaemia virus infection in Nigerian indigenous chickens. Onderstepoort Journal of Veterinary Research, 72:101103.

IMAI, K., MASE, M., TSUKAMOTO, K., HIHARA, H. \& YUASA, N. 1999. Persistent infection with chicken anaemia virus and some effects of highly virulent infectious bursal disease virus infection on its persistency. Research in Veterinary Science, 67:233-238.

ISLAM, M.R., JOHNE, R., RAUE, R., TODD, D. \& MULLER, H. 2002. Sequence analysis of the full-length cloned DNA of a chicken anemia virus (CAV) strain from Bangladesh: evidence for genetic grouping of CAV strains based on the deduced VP1 amino acid sequences. Journal of Veterinary Medicine (B), 49:332-337.

McNULTY, M.S. 1991. Chicken anaemia agent: a review. Avian Pathology, 20:187-203.

McNULTY, M.S., MACKIE, D.P., POLLOCK, D.A., McNAIR, J., TODD, D., MAWHINNEY, K.A., CONNOR, T.J. \& McNEILLY, F. 1990. Production and preliminary characterization of monoclonal antibodies to chicken anemia agent. Avian Diseases, 34:352-358.

MEEHAN, B.M., TODD, D., CREELAN, J.L., EARLE, J.A.P., HOEY, E.M. \& MCNULTY, M.S. 1992. Characterization of viral DNAs from cells infected with chicken anaemia agent: sequence analysis of the cloned replicative form and transfection capabilities of cloned genome fragments. Archives of Virology, 124:301-319.

NOTEBORN, M.H.M., DE BOER, G.F., VAN ROOZELAAR, D.J., KARREMAN, C., KRANENBURG, O., VOS, J.G., JEURISSEN, S.H.M., HOEBEN, R.C., ZANTEMA, A., KOCH, G., VAN ORMONDT, H. \& VAN DER EB, A.J. 1991. Characterization of cloned chicken anemia virus DNA that contains all elements for the infectious replication cycle. Journal of Virology, 65:3131-3139.

OHORE, O.G., OZEGBE, P.C., EMIKPE, B.O. \& OKOJIE, V.E. 2002. A survey of antibodies to Newcastle disease virus in apparently healthy Nigerian indigenous chickens (Gallus gallus domesticus) in Ibadan using ELISA. African Journal of Clinical \& Experimental Microbiology, 3:38-40.

OLUWAYELU, D.O., TODD, D., BALL, N.W., SCOTT, A.N.J., OLADELE, O.A., EMIKPE, B.O., FAGBOHUN, O.A., OWOADE, A.A. \& OLALEYE, O.D. 2005. Isolation and preliminary characterization of chicken anemia virus from chickens in Nigeria. Avian Diseases, 49:446-450.

OLUWAYELU, D.O. 2006. Isolation and characterization of chicken infectious anemia virus in southwestern Nigeria. Ph.D. thesis, University of Ibadan.

OWOADE, A.A., OLUWAYELU, D.O., FAGBOHUN, O.A., AMMERLAAN, W., MULDERS, M.N. \& MULLER, C.P. 2004. Serologic evidence of chicken infectious anemia in commercial chicken flocks in Southwest Nigeria. Avian Diseases, 48: 202-205.

RENSHAW, R.W., SOINE, C., WEINKLE, T., O'CONNELL, P.H., OHASHI, K., WATSON, S., LUCIO, B., HARRINGTON, S. \& SCHAT, K.A. 1996. A hypervariable region in VP1 of chicken anemia virus mediates rate of spread and cell tropism in tissue culture. Journal of Virology, 70:8872-8878.

TAMURA, K., DUDLEY, J., NEI, M. \& KUMAR, S. 2007. MEGA4: Molecular Evolutionary Genetics Analysis (MEGA) software version 4.0. Molecular Biology and Evolution, 24:1596-1599.

YUASA, N., TANIGUCHI, T., IMADA, T. \& HIHARA, H. 1983. Distribution of chicken anemia agent (CAA) and detection of neutralizing antibody in chicks experimentally inoculated with CAA. National Institute of Animal Health Quarterly (Japan), 23:78-81. 